Strategic R\&D location in European manufacturing industries

René Belderbos, Elissavet Lykogianni and Reinhilde Veugelers

DEPARTMENT OF MANAGERIAL ECONOMICS, STRATEGY AND INNOVATION (MSI) 


\title{
Strategic R\&D Location in European Manufacturing Industries
}

\author{
RENÉ BELDERBOS \\ Katholieke Universiteit Leuven and Eindhoven University of Technology \\ ELISSAVET LYKOGIANNI \\ Katholieke Universiteit Leuven \\ REINHILDE VEUGELERS \\ EC-BEPA, Katholieke Universiteit Leuven and CEPR
}

\begin{abstract}
We develop and empirically test a model of foreign $R \& D$ investments that takes into account strategic interaction in R\&D location decisions by multinational firms in the context of R\&D spillovers and foreign technology sourcing strategies. In a two-country, two-firm model with cross investments, the optimal share of $R \& D$ performed abroad depends on the efficiency of intra-firm international technology transfer, the degree of inter-firm R\&D spillovers, the intensity of product market competition, and the importance of the general knowledge pool. The impact of these factors differs markedly between technology leading firms and technology laggards. We find support for most of the predictions of the model in an empirical analysis of patents based on innovations in foreign countries by 131 leading European manufacturing firms in 22 ISIC industries in 19961997. For technology leaders, the share of patents originating in other EU countries responds positively to host country product market competition and is strongly increasing in the level of intellectual property rights protection. Foreign R\&D by technology laggards is discouraged by host country competition but increases with the efficiency of (reverse) technology transfer. Foreign R\&D of both leaders and laggards increases with the size of the local knowledge pool and the size of production operations in the host country.
\end{abstract}

Keywords: Multinational Firms, R\&D, R\&D spillovers, FDI

JEL classification: D21, F23, L16

The authors acknowledge support from KU Leuven grant OT/04/07A. Veugelers acknowledges support from the Belgian Federal Government DWTC (IUAP P5/11/33). 


\section{Introduction}

The internationalization of $R \& D$ by multinational firms is a phenomenon that has attracted growing interest among economists, management scholars, practitioners and policy makers (OECD 2005). An expanding literature has developed focusing on the determinants and role of R\&D conducted in foreign affiliates (e.g. Kuemmerle 1997, Frost 2001, Florida 1997, Belderbos, 2001; 2003; Kuemmerle, 1999; von Zedtwitz and Gassman, 2002; Odagiri and Yasuda, 1999; Zejan, 1990; Kumar 1996; Chung and Alcacer, 2002; Reger 2001, Le Bas and Sierra 2002) and the possible impact of such R\&D and overseas knowledge sourcing on productivity of parent operations (Iwasa and Odagiri, 2003; Griffith, Harrison, and van Reenen, 2003, Fors, 1996). This literature suggests that whereas traditionally overseas R\&D was conducted to adapt home-developed technologies to foreign markets ('home base exploiting' $R \& D$ ), foreign $R \& D$ activities are now becoming more important vehicles to access local technological expertise abroad and to create new technologies ('home base augmenting' R\&D).

One issue that has been broadly neglected in the literature on determinants and effects of foreign $R \& D$ is the role of strategic considerations in $R \& D$ decisions by firms operating in oligopolistic industries. Such considerations can be expected to be important, as overseas $\mathrm{R} \& \mathrm{D}$ is typically conducted by large multinational enterprises that operate subsidiaries in each others' home markets. Strategic interaction between R\&D decisions have received substantial attention in the theoretical studies in industrial organization that have emphasized the role of inter-firm R\&D spillovers (e.g. Petit and Sanna-Randaccio, 2000; Cassiman et al., 2002). A limited number of the theoretical papers have also examined strategic effects in foreign investment or foreign R\&D location decisions (e.g. Belderbos at al., 2004; Siotis, 1999, Bjorvatn and Eckel, 2001). However, to date no empirical evidence has been provided for consequences of strategic interactions in international R\&D location decisions.

This paper addresses this gap in current knowledge, by developing and empirically testing a model of foreign $R \& D$ investments that takes into account strategic interaction in $R \& D$ location decisions by multinational firms in the context of $R \& D$ spillovers and foreign technology sourcing strategies. We expand and adapt a two-country two-firm model of strategic R\&D location decisions developed in Belderbos et al. (2004). Two multinational firms operating subsidiaries in each others' home markets decided on the share of R\&D to be conducted in the foreign subsidiary. They take into account the potential outgoing $R \& D$ spillovers to the rival firm, and foreign technology sourcing opportunities from the foreign 
rival and the general knowledge pool available in the host country. Knowledge sourcing requires an absorptive capacity which is only present in case of localized R\&D. The optimal share of R\&D performed abroad by a multinational firm depends on the efficiency of intrafirm international technology transfer, the degree of local inter-firm R\&D spillovers, and the intensity of product market competition. The model distinguishes between technology leading firms and technology laggards and finds that the impact of these factors differs markedly between the two types of firms. We find support for most of the predictions of the model in an empirical analysis of patents based on innovations in foreign countries by 131 leading European manufacturing firms in 22 ISIC industries in 1996-1997. For technology leaders, the share of patents originating in other EU countries responds positively to host country product market competition and is strongly increasing in the level of intellectual property rights protection. Foreign R\&D by technology laggards is discouraged by host country competition but increases with the efficiency of (reverse) technology transfer. Foreign R\&D of both leaders and laggards increases with the size of the local knowledge pool and the size of production operations in the host country.

The remainder of this paper is organized as follows. The next section presents the model of strategic R\&D location and derives the main predictions from this model. Section 3 describes the data set, variable construction and empirical model. Section 4 presents empirical results and section 5 concludes.

\section{A model of Strategic Interactions in R\&D Location Decisions}

Previous theoretical models focusing on foreign $R \& D$ decisions by multinational firms have mainly taken the perspective of a single multinational firm, treating domestic and foreign rival firms as a competitive fringe and thus ignoring strategic interaction among competing MNEs (Norback, 2001; Sanna-Randaccio and Veugelers, 2002). Other contributions have been more concerned with the effect of country-specific stocks of knowledge on R\&D decentralization (Franck and Owen, 2003), the geography of R\&D within a single country in the presence of R\&D spillovers (Gersbach and Schmutzler, 1999), location incentives of different types of R\&D (Cadot and Desruelle, 1998) or with strategic FDI rather than strategic R\&D (Siotis, 1999, Bjorvatn and Eckel, 2001). Belderbos et al. (2004) 
specifically focuses on strategic interactions in R\&D decisions between multinational firms based in different home countries.

In this paper we expand and adapt the two-country two-firm model of strategic R\&D location decisions developed in Belderbos et al. (2004). Two multinational firms operating subsidiaries in each others' home markets decided on the share of R\&D to be conducted in the foreign subsidiary. They take into account the potential outgoing R\&D spillovers to the rival firm, and foreign technology sourcing opportunities from the foreign rival and the general knowledge pool available in the host country. Knowledge sourcing requires an absorptive capacity which is only present in case of localized R\&D. In what follows, we describe the model setup and analytical results, while relegating derivations to the appendix.

\section{The model}

There are two multinational firms that decide on the optimal allocation of their R\&D budget $X_{i},(i=1,2)$ between home and host country operations. The allocation of R\&D determines the effective knowledge base available at headquarters and in the foreign subsidiary. These effective knowledge bases in turn have a positive impact on profits. Denoting $\lambda_{i}$ as the share of firm's $i$ R\&D allocated to the foreign affiliate, the profit function of firm $i$ is given by:

$$
\Pi_{i}=\Pi_{i}^{P}\left(K_{i}^{P}, K_{j}^{S}\right)+\Pi_{i}^{S}\left(K_{i}^{S}, K_{j}^{P}\right)-\frac{\delta}{2}\left(\lambda_{i} X_{i}\right)^{2}
$$

Profits of firm $i$ are the sum of profits of the parent firm at home (p) and profits of the foreign subsidiary (s) minus the cost of dispersing $R \& D$ and transferring $R \& D$ resources abroad. We assume that this cost function is concave in the share of R\&D located abroad and the level of R\&D expenditures, to capture the effect of scale and scope advantages of centralized R\&D operations. The parameter $\delta$ measures the size of the cost disadvantage of dispersed R\&D operations.

Profits of the subsidiary and parent operations are an increasing function of the knowledge bases available $(\mathrm{K})$ in these locations, by reducing costs and/or enhancing demand. On the other hand, the rival firm's knowledge base reduces the relative cost or the demand advantage of the firm, and negatively impacts its profits. We assume: 
$\frac{\partial \Pi_{i}}{\partial K_{i}^{P}}=\frac{\partial \Pi_{i}}{\partial K_{i}^{S}}=b$ and $\frac{\partial \Pi_{i}}{\partial K_{j}^{P}}=\frac{\partial \Pi_{i}}{\partial K_{j}^{S}}=-\mu b$

The impact of the knowledge stocks on profits are captured by the parameter $b$, which can reflect the size of the market as well the technological opportunities in the industry. For simplicity, we assume this parameter to be equal across firms and markets. Parameter $\mu$ measures the impact of rival firm's knowledge base on firm profits, and is a measure of the intensity of product market competition. We make the conventional assumption that the marginal impact of rival's knowledge bases on profits is smaller than the marginal impact of the own knowledge base $(0<\mu<1)$.

\section{Effective Knowledge Bases}

Before we can analyze the firm's optimal localization decisions, we need to characterize the composition of firms' effective knowledge bases, both at the parent and at the subsidiary level. With respect to own $R \& D$ resources, we allow the firms to differ in the size of their total own R\&D resources. Firm 1 is assumed to possess larger R\&D resources and, therefore, characterized as the 'technology leader', while firm 2 is the 'technology laggard', i.e.: $X_{1}>X_{2}$. The relative technology lead of the leader, denoted by the parameter $s$,

represents the 'laggard to leader R\&D ratio': $s=\frac{X_{2}}{X_{1}}$ (with $0<s<1$ ). The higher is $s$, the smaller is the technology gap between the leader and the laggard.

Firms can transfer knowledge internally from parent to subsidiary and vice versa. These internal knowledge transfers cross national boundaries; hence they are international in scope. They are also imperfect, not only because of the costs associated with transferring knowledge internationally within the firm, but also because of the need to adapt the transferred know-how to local conditions. For analytical convenience, we assume symmetry between the two firms in terms of internal transfer efficiency, which is indicated by the parameter $\beta(0<\beta<1)$, representing the share of knowledge that 'survives' if transferred intra-firm across countries. 
Inter-firm knowledge spillovers between the two firms are geographically bounded and are assumed to occur only between headquarters and subsidiaries located in the same country. This is in line with the agglomeration literature, which suggests that inter-firm, external knowledge dissemination requires geographic proximity, (e.g. Gersbach \& Schmutzler, 1999). Spillovers are bi-directional: a firm benefits from incoming spillovers if it co-locates R\&D, but this will also increase outgoing spillovers to the rival firm. Parameter $\alpha$ represents the share of knowledge that spills over inter-firm with $0<\alpha<1$.

General knowledge spillovers are spillovers originating from non-rival firms' local R\&D activities and $R \& D$ conducted at public institutions. They are treated as localized and benefiting from them requires an R\&D presence in the country. We allow for differences in the size of the general knowledge pool available in the two countries, with $G_{2}=g G_{1}$ (with $g$ an index of the relative technology advantage of country 2). Inter-firm and general knowledge spillovers require, and are enhanced by, the absorptive capacity of the firm in the country as represented by the firm's own local R\&D resources.

Given the above assumptions, the effective knowledge base at the parent and subsidiary are given by:

$$
\begin{aligned}
& K_{1}^{P}=\left(1-\lambda_{1}\right) X_{1}+\gamma G_{1}\left(1-\lambda_{1}\right) X_{1}+\alpha \lambda_{2} X_{2}\left(1-\lambda_{1}\right) X_{1}+\beta\left[\lambda_{1} X_{1}+\gamma G_{2} \lambda_{1} X_{1}+\alpha\left(1-\lambda_{2}\right) X_{2} \lambda_{1} X_{1}\right] \\
& K_{1}^{S}=\lambda_{1} X_{1}+\gamma G_{2} \lambda_{1} X_{1}+\alpha\left(1-\lambda_{2}\right) X_{2} \lambda_{1} X_{1}+\beta\left[\left(1-\lambda_{1}\right) X_{1}+\gamma G_{1}\left(1-\lambda_{1}\right) X_{1}+\alpha \lambda_{2} X_{2}\left(1-\lambda_{1}\right) X_{1}\right]
\end{aligned}
$$

The effective knowledge base of the parent at headquarters consists of three parts. The first term represents the internal $\mathrm{R} \& \mathrm{D}$ allocated to the parent. The second term is the internal knowledge flowing back from the subsidiary of firm $i$ to the parent (intra-firm spillover): it is the combination of the internal knowledge transfer efficiency parameter $\beta$ and the potential knowledge base to transfer, with the latter consisting of the subsidiary's own R\&D and incoming external spillovers in the foreign country (the benefits to the parent from foreign knowledge sourcing). The third term represents incoming external (or inter-firm) knowledge spillovers in the home country of firm $i$, which originate from the R\&D resources that rival firm $j$ has located abroad to its subsidiary. In addition, the parent firm sources knowledge from the locally available general knowledge stock. The main assumptions concerning the different knowledge flows are illustrated in Figure 1. The knowledge base of the subsidiary in the host country has a similar structure. 
Insert Figure 1

\section{Optimal R\&D Allocation}

The R\&D localization ratio $\left(\lambda_{i}\right)$ will affect the effective knowledge base of both the parent and the subsidiary through all three components. It will influence not only the R\&D resources available at each plant, but also the internal knowledge transfers and, through the absorptive-capacity effect, also the incoming external spillovers. Using equations (1)-(3.2), we solve for the optimal share of R\&D allocated to the subsidiary of firm 1 and firm 2 . The first-order conditions yield the following best response functions ${ }^{1}$ :

$$
\begin{aligned}
& R_{1}\left(\lambda_{1}\right)=\frac{b(1+\beta)\left[(g-1) \gamma G_{1}+s \alpha(1-\mu) X_{1}\right]-\delta \lambda_{1} X_{1}}{2 b s \alpha(1+\beta)(1-\mu) X_{1}} \\
& R_{2}\left(\lambda_{1}\right)=\frac{b(1+\beta)\left[(1-g) \gamma G_{1}+\alpha(1-\mu) X_{1}\right]-2 b(1+\beta) \alpha(1-\mu) X_{1} \lambda_{1}}{s \delta X_{1}}
\end{aligned}
$$

The reaction functions are downward sloping and R\&D localization of firms $i$ and $j$ are strategic substitutes. This reflects the agglomeration enhancing impact of inter-firm knowledge spillovers: firm $i$ can increase the impact of R\&D resources on its knowledge bases by responding to an increase in foreign $\mathrm{R} \& \mathrm{D}$ by rival firm $j$ (in the home country of firm $i$ ) with increased concentration of R\&D resources in its home country. Increasing R\&D at home enhances the firm's absorptive capacity and allows it to benefit more from the expanded sourcing opportunities due to the rival's increase in local R\&D. From 4.1

Solving for the optimal $\lambda$ gives the following expressions for firm 1 , the technology leader and for firm 2, the technology laggard:

$$
\lambda_{1}^{*}=\frac{b(1+\beta)\left[\gamma(1-g)(\delta+2 b \alpha(1+\beta)(1-\mu)) G_{1}+\alpha[s \delta-2 b \alpha(1+\beta)(1-\mu)](1-\mu) X_{1}\right]}{\left(\delta^{2}-4 b^{2} \alpha^{2}(1+\beta)^{2}(\mu-1)^{2}\right) X_{1}}
$$

\footnotetext{
${ }^{1}$ The existence and stability conditions are provided in the appendix.
} 


$$
\lambda_{2}^{*}=\frac{b(1+\beta)\left[\gamma(g-1)(\delta+2 b \alpha(1+\beta)(1-\mu)) G_{1}+\alpha[\delta-2 b s \alpha(1+\beta)(1-\mu)](1-\mu) X_{1}\right]}{\left(\delta^{2}-4 b^{2} \alpha^{2}(1+\beta)^{2}(\mu-1)^{2}\right) s X_{1}}
$$

\section{Predictions}

From (5.1) and (5.2) we can derive a number of predictions concerning the impact of the key parameters of the model: the intensity of spillovers $\alpha$, the efficiency of international technology transfer $\beta$, and the intensity of product market competition $\mu$, and the relative size of the local pool of knowledge $g$. The expressions for these derivations are relegated to the appendix.

Analytical results for the intensity of spillovers $\alpha$ suggest that given a relatively strong technology leadership position of the leading firm $\left(s<s_{i}^{\alpha} \quad i=1,2\right)$, the leader will decrease the share of $R \& D$ located abroad in a response to greater $R \& D$ spillovers, while the laggard increases the share of foreign $\mathrm{R} \& \mathrm{D}$ : This result reflects the leader's interest to reduce potential knowledge dissipation and, on the other hand, the laggard's stronger knowledge sourcing motivation.

Proposition 1: Under strong technological leadership, the technology leader responds to greater inter-firm $R \& D$ spillovers by reducing the share of foreign $R \& D$, while the technologically lagging firm increases it.

The impact of the efficiency of international technology transfer intra-firm also differs for leaders and laggards. Given a relatively strong technology lead $\left(s<s_{i}^{\beta}\right)$, the leader decreases the share of $R \& D$ abroad in response to an increased transfer efficiency while the laggard again increases foreign R\&D. Increased efficiency strengthens the incentive of the leader to centralize $R \& D$ at home and reduce decentralization costs, while its subsidiary relies on knowledge transferred from the home laboratory. Foreign $R \& D$ allows the laggard to benefit from more reverse transfer of foreign sourced knowledge, an effect which is more important for the laggard than for the leader 
Proposition 2: Under strong technological leadership, the technology leader responds to greater efficiency of international knowledge transfer by reducing the share of foreign $R \& D$, while the technologically lagging firm increases it.

The intensity of product market competition $\mu$ has an opposite effect from the impact of intra firm knowledge transfer efficiency and R\&D spillovers. Under relatively strong technology leadership $\left(s<s_{i}^{\mu}\right.$ with $s_{i}^{\mu}=s_{i}^{\alpha}$ ), the leader increases the share of R\&D abroad while the laggard reduces it. Increased product market competition makes the leader more aggressive in the rival's home market and leads to a larger incentive for R\&D decentralization to capture a larger share of profits in the foreign market, which is possible because of the weakness of the local rival in its home market. This effect is stronger than the detrimental impact of increased outgoing external spillovers in the foreign market with stronger product market competition. For the laggard, increased product market competition leads to a response to defend its home market position by keeping more $\mathrm{R} \& \mathrm{D}$ resources at home.

Proposition 3: Under strong technological leadership, the technology leader responds to greater product market competition by increasing the share of foreign $R \& D$, while the technologically lagging firm reduces it.

An asymmetry in the optimal R\&D allocation between technology leaders and laggards is not observed if it concerns the impact of the relative size of the general knowledge pool. Both firms increase foreign $R \& D$ if the size of the relative general knowledge pool abroad increases.

Proposition 4: Both technology leaders and technology laggards increase the share of $R \& D$ abroad in response to an increase in the relative size of the general knowledge pool of the host country.

\section{Data and Empirical Methods}

In the empirical analysis we aim to find evidence for the proposition of the model of strategic R\&D location. We use data on domestic and foreign innovation activities of 131 
European firms that are leading in European manufacturing industries. The dataset combines information on their patenting activities and location of innovative activities that resulted in those patents, and their production activities in $15 \mathrm{EU}$ countries and 22 (2-digit ISIC) manufacturing industries in 1996-1997. The firms are in the top-5 of EU manufacturing in at least one industry. ${ }^{2}$ Patent data are patent applications with the European Patent Office in the years 1996-1997. The patent applications are assigned to a country on the basis of the address of the inventor listed in the patent information. Patents are assigned to ISIC industries based on the MERIT patent to industry concordance, adapted to third revision ISIC classifications. This concordance attaches to each international patent classification code (IPC, describing the technological domain of the patent) a probability that it is originating in a specific ISIC industry, based on the industries of applicant firms.

The leading EU firms applied for 14298 patents in these years, of which 2666 were based on R\&D activities outside the home country. Table 2 shows the matrix of the location of R\&D activities leading to patent applications. It is shown that Germany is an important host country for non-German EU firms' R\&D activities. Germany is also a major home country of multinational firms active in foreign R\&D in other EU countries. France is also a major location of other EU firms' R\&D operations, followed by the UK and Belgium.

\section{Insert Table 1.}

The dependent variable in the empirical model follows the definition in the strategic $R \& D$ location model. It is the ratio of $R \& D$ activities (as derived from patent application) in EU country $\mathrm{j}$, to total R\&D activities in home country $\mathrm{i}$ and host country $\mathrm{j}$, while we differentiate per industry $\mathrm{k}$. This foreign $\mathrm{R} \& \mathrm{D}$ ratio is defined as $\lambda_{i j k}=p a t_{i j k} /\left(p a t_{i j k}+p a t_{i h k}\right), h \neq j$. For each leading firm we observe this ratio of foreign to domestic R\&D for each (potential) EU host country as long as the firm has patenting output in the particular industry. In total, this gave us 972 observations host country patents of the EU firms in the dataset.

We distinguish between leaders and laggards based on the number of patent applications in the industry by the EU firms. The technology leader in the European industry

\footnotetext{
${ }^{2}$ The data on production locations of EU firms are taken from Van Pelt et al. (2001). In addition to the EU firms, 28 non-EU firms are identified among Europe's largest manufacturers. These firms are excluded from the empirical analysis as they do not have a 'home country' within the EU. Patents and production of these firms are taken into account when calculating leadership and concentration measures.
} 
is defined as the firm with the largest number of EU patents applications that are classified within that industry. The technology advantage of the leader is the size of the technology gap between leader and the laggards and defined as the ratio of the laggards' patents in industry $k$ across all countries $j$ over the number of patents of the leading firm L: lead $_{i k}=\sum_{j}$ pat $_{i j k} / \sum_{j}$ pat $_{L j k}$. The variable lead takes the value one for EU leaders.

The first independent variable is the intensity of $R \& D$ spillovers (proposition 1). These external spillovers are determined by technology specific factors (such as the complexity of know-how affecting the degree of appropriation, and the effectiveness of the legal appropriation regime for specific technologies) and by country specific factors (the strength of IPR protection). We focus here on the country specific variation, by taking as a proxy for the R\&D spillovers and appropriability conditions, the strength of a country's patent protection. The index of intellectual property rights is due to Ginarte and Park (1997) and measures the strength of patents laws and enforcement. We include the variable $I P R_{h j}$, the ratio of the index of IPR protection in host country $j$ over the IPR protection index in firm's $i$ home country. Countries with better IPR protection should see more R\&D allocation by the leader but not by the laggard. ${ }^{3}$

Proposition 2 calls for the inclusion of a proxy for the efficiency of international (bilateral) technology transfer by multinational firms. An increase in the intra-firm knowledge transfer reflects more efficient transfer of knowledge within the firm, e.g. because of better knowledge management practices or information and communication technologies. It also reflects a reduction in differences in markets between the two countries, reducing the need to adapt knowledge transferred across countries, and the fact that coordination costs reduce with geographic distance. Hence as proxy for this transfer efficiency measure we can take a measure of 'closeness' of product markets in the two countries for the industry related to the intensity of export and import flows in the industry between the countries. We use the indicator of intra-industry trade: transfer efficiency $=\left(X_{h j k}+M_{h j k}\right) /\left(\operatorname{Prod}_{h k}+\operatorname{Prod}_{j k}\right), h \neq j$, where $X_{h j k}$ represents the exports in industry $k$ from country $j$ (the host country) to country $h$ (the home country of firm $i$ ), $M_{h j k}$ are the imports in industry $k$ of country $j$ from country $h$, and Prod represent the value of production in the industry in the two countries (data are taken

\footnotetext{
${ }^{3}$ Strictly speaking, the model in section 2 and proposition 1 do not differentiate between spillovers (IPR protection) in the home and host countries. Further analysis (Belderbos et al. 2004) shows that the results can be extended to the relative intensity of R\&D spillovers in the host country. The same reasoning applies to the implementation of proposition 3 as the relative concentration ratio.
} 
from the OECD STAN database). Higher values for this measure indicate greater similarities between markets and easier use of foreign technologies. Proposition 2 predicts a negative impact on foreign R\&D for leaders and a positive impact for laggards.

Proposition 3 suggests the use of an indicator of product market competition. We use a measure of production concentration in the home and host country to measure this impact. Herfindahl is the ratio of the host country Herfindahl index of concentration relative to the home country's Herfindahl index: $\sum_{i=1}^{n}\left(m_{i j k}\right)^{2} / \sum_{i=1}^{n}\left(m_{i h k}\right)^{2}$ with $m_{i j k}$ the production share of firm $i$ in country $j$ and industry $k, m_{i h k}$ the production share of firm $i$ in its home country $h$ and industry $k$, and $n$ being the number of EU and non-EU leading firms producing in country $j$ and industry $k$. Proposition 3 suggests a negative impact of Herfindahl on the foreign R\&D ratio for leaders but a positive impact for laggards.

Proposition 4 suggests a positive impact on foreign $R \& D$ of the size of the general knowledge pool in a host country relative to the home country. As proxy for the relative size of the knowledge base we take the number of patents granted in 1996-1997 to residents in the countries and classified in the industry: Knowledge Pool $=$ Patents $_{j k} /$ Patents $_{h k}, h \neq j$. Proposition 4 suggests a positive impact on the share of host country R\&D for both leaders and laggards.

The theoretical model did not take into account differences in the size of firms' operations in the home and host country (i.e. differences in the parameter $b$ ). The scale of production is expected to have an important impact on R\&D expenditures, as larger operations increase the return on in particular $R \& D$ to adapt products and processes to local market circumstances (e.g. Belderbos, 2003). Hence we include firm size as a control variable. Firm size is defined as the share of production of firm $i$ in a foreign country $j$ in industry $k$ over the sum of production of firm $i$ in its home country $(h)$ in industry $k$ and its production at country $j$ in industry $k=\operatorname{prod}_{i j k} /\left(\operatorname{prod}_{i j k}+\operatorname{prod}_{i h k}\right), h \neq j$.

The dependent variable, the ratio of host country R\&D relative to $R \& D$ in the home and host countries combined is restricted in the interval $[0,1]$, we use employ a two-limit Tobit model to related the dependent variable to the explanatory variables. Statistics on the dependent and explanatory variables are provided in Table 2.

\section{Insert Table 2}




\section{Empirical Results}

The results of the Tobit model are presented in Table 3. The model is highly significant and generally performs well with a pseudo $\mathrm{R}^{2}$ of 37,5 . Proposition 1 is only partially supported by the empirical results. Indeed, technology leaders are highly sensitive to the level of IPR protection (reducing outgoing R\&D spillovers) abroad, as the interaction between the IPR ratio and the leadership ratio (lead) is positive and significant. Laggards, however, are also increasing the ratio of foreign $R \& D$ in response to better IPR protection, though the magnitude of this effect is significantly smaller than the effect for leaders.

\section{Insert Table 3}

The estimated coefficients for transfer efficiency provide qualified support for proposition 2. The main coefficient of this variable is positive, indicating that multinational firms generally located more $R \& D$ in a host country industry if it is relatively effective and less costly to transfer and use foreign technologies. In contrast, the interaction effect with lead is negative and significant, confirming that technology leaders are significantly less likely to increase foreign $R \& D$ in response to greater transfer efficiency. The coefficient of the interaction effect, however, is not greater than the coefficient of the main effect, which implies that transfer efficiency does not impact foreign R\&D negatively. The empirical results provide full support for proposition 3. The ratio of host to home country concentration (herfindahl) indices has a positive and significant general impact of foreign $R \& D$, while the interaction effect with the leadership ratio is negative and significant. The magnitudes of these effects are such that relative concentration has a negative impact for technology leaders. Hence, while technology laggards reduce foreign $R \& D$ in response to greater product market competition there, technology leaders increase the foreign $R \& D$ ratio to make use of their technology advantage and capture a larger share of the local market. Laggards in contrast, concentrate $R \& D$ at home to defend their home market position.

The empirical results also support proposition 4 in full. The relative size of the general knowledge pool in the host country has a positive and significant impact on the foreign $R \& D$ ratio. This is not different for leaders, as the interaction effect with the leadership ratio is insignificant. Hence the relative strength of a country's technology and knowledge base in an industry attracts R\&D by both leaders and lagging firms, as predicted. Finally, the size of the 
firm's host country production relative to home market operations in the industry has the expected positive impact on the foreign $R \& D$ ratio.

\section{Conclusions}

In this paper we develop and empirically test a model of foreign $R \& D$ investments that takes into account strategic interaction in $R \& D$ location decisions by multinational firms in the context of R\&D spillovers and foreign technology sourcing strategies. When deciding on $R \& D$ internationalization, firms take into account the benefits in terms of incoming $R \& D$ spillovers in the local market from the rival firm and better access to the general knowledge pool in the host country (technology sourcing). On the other hand, firms also face greater risk of dissipation of know-how from their own R\&D abroad to their rivals, which would favor reliance on international intra-firm technology transfer from headquarters to the host country. The model takes into account the 'two faces' of R\&D: the positive impact on absorptive capacity which increases the benefits of incoming spillovers, as well as the direct positive effect on the firm's knowledge base. Absorptive capacity (local R\&D) is a prerequisite for local technology sourcing. In a two-country, two-firm model with international cross investments, the optimal share of $R \& D$ performed abroad depends on the efficiency of intrafirm international technology transfer, the degree of inter-firm R\&D spillovers, the intensity of product market competition, and the importance of the general knowledge pools. The impact of these factors on the optimal share of foreign R\&D differs markedly between the technologically leading firm (the firm with the highest $R \& D$ expenditures) and the technologically lagging firm if the gap between the two firms is important.

We find partial support for the predictions of the model in an empirical analysis of foreign $\mathrm{R} \& \mathrm{D}$ (as reflected in patent applications) in EU countries by 131 leading European manufacturing firms in 22 ISIC industries in 1996-1997. Greater efficiency of intra-firm technology transfer abroad leads to increased $R \& D$ abroad by technology laggards, because their home market operations can benefit from more effective foreign technology sourcing. Technology leaders are much less responsive to this transfer efficiency, as their host market operations can rely more effectively on technology developed at home and transferred abroad.

Weaker R\&D spillovers due to a greater effectiveness of intellectual property rights protection in the host country relative to the home country increases R\&D by both leaders and laggards, but technology leaders are significantly more responsive to this factor. Technology 
leaders face greater appropriability concerns, but for technology laggards such concerns are mitigated by technology sourcing motives in the host country. The results imply that there is a tendency of R\&D to agglomerate in the country with the stronger IPR protection (c.f. Branstetter et al., 2003). Weaker product market competition (higher concentration) in the host country relative to the home country encourages foreign R\&D by the lagging firms, but has a negative impact on foreign R\&D by technology leaders. More intense product market competition encourages leading firms to engage in offensive foreign $R \& D$ in order to make use of their technology advantage and to capture a larger share of the local market. Laggards in contrast, are more likely to concentrate $R \& D$ at home to defend their home market position. Finally, both leaders and laggards are attracted to countries with relatively larger general knowledge pools relevant to the industry.

The findings demonstrate that predictions from a model of strategic R\&D location decisions by multinational firms are relevant in the empirical setting of EU firms' foreign R\&D activities. At the same time, the results indicate potentially fruitful avenues for further research and improvement. Theoretical modeling should further focus on the impact of asymmetries between host and home countries on R\&D location decisions. Empirical tests could improve the empirical proxies for in particular technology transfer efficiency and IPR (spillovers). Measures of intra-firm technology transfer efficiency could be derived from industry- and country-specific measures of patent citations between home and host countries. Since appropriability conditions and spillovers differ among industries, industry level data on IPR would bring out more detailed effects of host and home country conditions. Data from the Community Innovation Surveys may be an interesting source of information on industry- and country-specific importance of patent protection and other appropriability mechanisms.

\section{References}

Belderbos, R.A., 2001 Overseas Innovations by Japanese Firms: An Analysis of Patent and Subsidiary Data, Research Policy, Vol. 30 (2), 313-332.

Belderbos, R. A., 2003 Entry Mode, Organizational Learning, and R\&D in Foreign Affiliates: Evidence from Japanese Firms, Strategic Management Journal, 24 (3), 235-259.

Belderbos, R. A., E. Lykogianni, R. Veugelers, 2004, Strategic R\&D Location by Multinational Firms: Spillovers, Technology Sourcing, and Competition, CEPR Discussion Paper series, no. 5060. 
Bjorvatn K. and C. Eckel, 2001: 'Technology Sourcing and Foreign Direct Investment', Norwegian School of Economics Discussion Paper n. 28/01.

Brantstetter, L G., R. Fisman, and C. F. Foley et al, 2004, Do Stronger Intellectual Property Rights Increase International Knowledge Transfer? Empirical Evidence from U.S. FirmLevel Panel Data, Working paper.

Cadot, O., D. Desruelle, 1998, R\&D: who does the R, who does the D?, Journal of International Economics, 46, 87-103.

Cohen, W. and D. Levinthal, 1989, Innovation and learning: the two faces of R\&D, Economic Journal, 569-96.

Ethier W., Markusen J.R., 1996, Multinational firms, technology diffusion and trade, Journal of International Economics 41, 1 - 28.

Florida, R., 1997, The Globalization of R\&D: Results of Survey of Foreign-Affiliated R\&DLaboratories in the USA, Research Policy, 26, 85-102.

Fors, G., 1996, Technology transfer to foreign affiliates by multinational enterprises, IUI working paper series, no. 456.

Franck, B. and Owen, R, 2003, Fundamental R\&D Spillovers and the Internationalization of a Firm’s Research Activities, Cowles Foundation Discussion Paper, No. 1425.

Frost, Thomas, 2001, The geographic sources of foreign subsidiaries' innovation, Strategic Management Journal, 22, 101-124.

Gersbach and Schmutzler, 1999, External Spillovers, Internal Spillovers and the Geography of Production and Innovation, Regional Science and Urban Economics, 29 (6), 679-696.

Ginarte, and Park, 1997, Determinants of patent rights: A cross-national study Research Policy 26 (3), 283-301.

Gupta, A.K., \& Govindarajan, V. 2000. Knowledge flows within multinational corporations. Strategic Management Journal. 21: 473-496.

Kuemmerle, W., 1997, Building Effective R\&D Capabilities Abroad, Harvard Business Review, March / April, 61-70.

Kumar, N., 1996, Intellectual property protection, market orientation and location of overseas R\&D activities by multinational enterprises, World Development 24: 673-688.

Lee, J. Y. and E. Mansfield, 1996, Intellectual Property Rights Protection and U.S. Foreign Direct Investment, Review of Economics and Statistics, 79: 181-186.

Mansfield, E., 1995, Intellectual property protection, Direct Investment and technology transfer: Germany, Japan and the United States, World Bank, International Finance Corporation, Discussion Paper 27, 32 pp. 
Norback, P.-J., 2001, Multinational firms, technology and location, Journal of International Economics, 54, 449-69.

Odagiri H. and Yasuda H., 1996, The determinants of overseas R\&D by Japanese firms: an empirical study at the industry and company levels, Research Policy 25: 1059- 1079.

OECD, 2005, Background report to the Conference on "Internationalization of R\&D", Brussels, March.

Petit M.L. and F. Sanna-Randaccio, 2000, Endogenous R\&D and Foreign Direct Investment in International Oligopolies, International Journal of Industrial Organization, 18, 339367.

Raminez, P., 2003, The globalization of research among leading European and US pharmaceutical multinationals: the shift of European investment to the USA, CISC working papers no. 9.

Roberts E., 2001, Benchmarking Global Strategic Management of Technology, Research Technology Management, 44,2, pp. 25-36.

Sanna-Randaccio F. and R. Veugelers, 2001, Multinational Knowledge Spillovers with Centalized vs Decentralized R\&D, CEPR discussion paper, n. DP3151.

Siotis, G., 1999, Foreign Direct Investment Strategies and Firm Capabilities, Journal of Economics and Management Strategy, 8, 251-270.

Smarzynska, Beate, 2004, Composition of Foreign Direct Investment and Protection of Intellectual Property Rights: Evidence from Transition Economies, European Economic Review, vol. 18 (1), 39-62.

Van Pelt, A. et al. (2002), Sources of Leadership in EU Manufacturing, Ernst and Young, Leuven.

Zedtwitz, M. von, and Gassmann, O. (2002): Market versus Technology Drive in R\&D Internationalization: Four Different Patterns of Managing Research and Development, in: Research Policy, Vol. 31, 2002, No. 4, 569-588

Zejan, M., 1990, R\&D Activities in Affiliates of Swedish Multinational Firms, Scandinavian Journal of Economics, Vol. 92, No 3, pp. 487-500. 


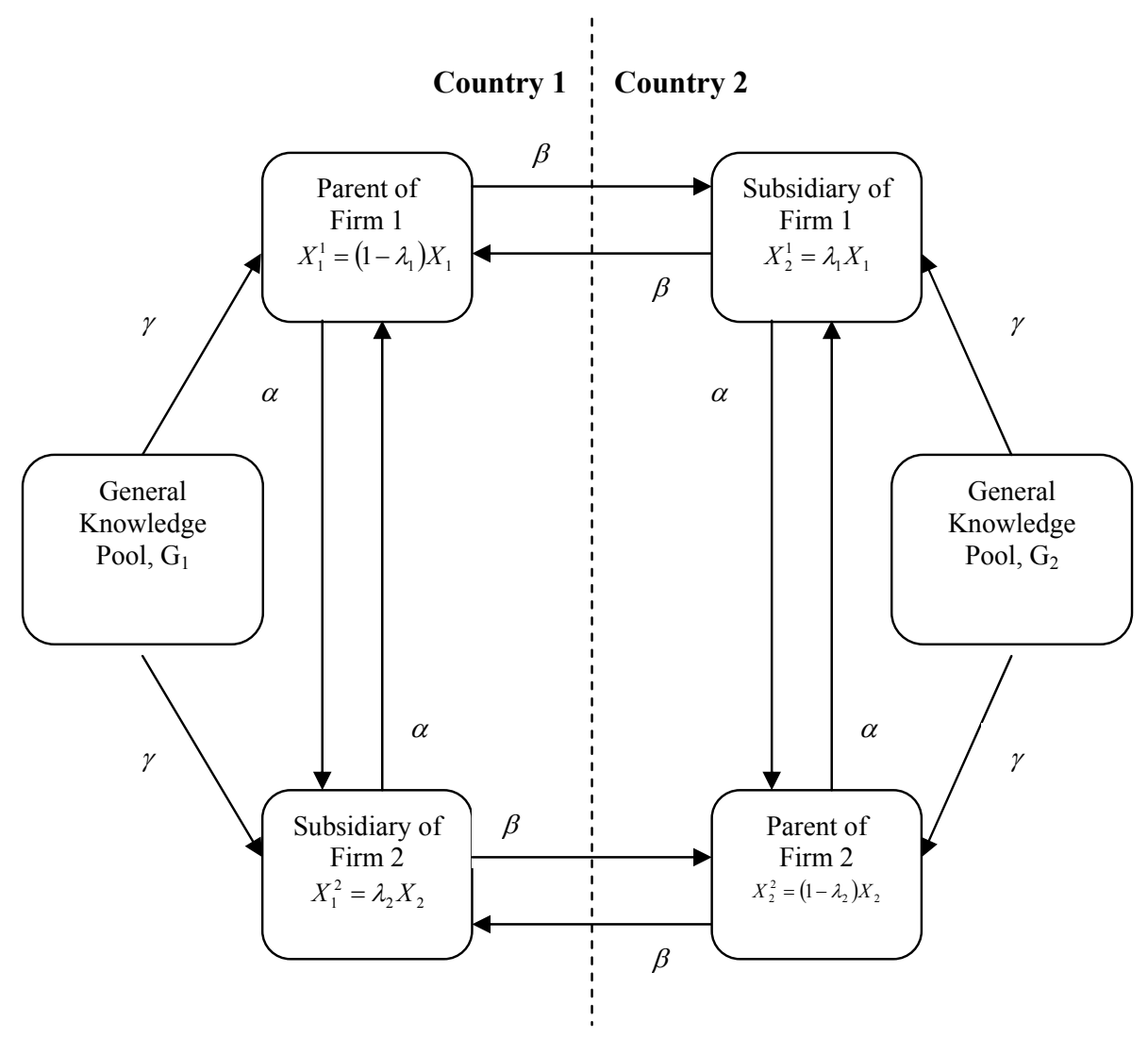

FIGURE 1: R\&D and Knowledge Flows 
Table 1: Patents Based on Foreign R\&D Activities by the Larges EU Manufacturing Firms, 1996-1997

\begin{tabular}{|c|c|c|c|c|c|c|c|c|c|c|c|c|c|c|c|}
\hline Host Country & & & & & & & & & & & & & & & \\
\hline Home Country & AT & BE & DE & DK & SP & FI & FR & GB & GR & IE & IT & NL & PO & SE & Total \\
\hline AT & & 0 & 0 & 0 & 0 & 0 & 0 & 0 & 0 & 0 & 0 & 0 & 0 & 0 & 0 \\
\hline BE & 0 & & 30 & 0 & 0 & 0 & 8 & 4 & 0 & 0 & 1 & 1 & 0 & 0 & 44 \\
\hline DE & 126 & 197 & & 17 & 46 & 0 & 120 & 107 & 1 & 2 & 44 & 51 & 0 & 46 & 756 \\
\hline DK & 0 & 0 & 0 & & 1 & 5 & 0 & 2 & 0 & 0 & 0 & 1 & 0 & 0 & 9 \\
\hline SP & 0 & 0 & 0 & 0 & & 0 & 0 & 0 & 0 & 0 & 0 & 0 & 0 & 0 & 0 \\
\hline FI & 0 & 0 & 30 & 12 & 0 & & 2 & 53 & 0 & 0 & 0 & 1 & 0 & 3 & 100 \\
\hline FR & 2 & 66 & 425 & 1 & 13 & 1 & & 38 & 0 & 0 & 22 & 6 & 0 & 1 & 575 \\
\hline GB & 0 & 23 & 93 & 0 & 1 & 0 & 88 & & 0 & 0 & 26 & 10 & 0 & 3 & 244 \\
\hline GR & 0 & 0 & 0 & 0 & 0 & 0 & 0 & 0 & & 0 & 0 & 0 & 0 & 0 & 0 \\
\hline IE & 0 & 0 & 0 & 0 & 0 & 0 & 0 & 0 & 0 & & 0 & 0 & 0 & 0 & 0 \\
\hline IT & 0 & 31 & 18 & 1 & 7 & 0 & 35 & 11 & 0 & 0 & & 2 & 0 & 0 & 104 \\
\hline NL & 14 & 17 & 196 & 0 & 1 & 0 & 136 & 67 & 0 & 0 & 8 & & 0 & 18 & 458 \\
\hline PO & 0 & 0 & 0 & 0 & 0 & 0 & 0 & 0 & 0 & 0 & 0 & 0 & & 0 & 0 \\
\hline SE & 8 & 4 & 161 & 13 & 1 & 28 & 18 & 25 & 0 & 0 & 68 & 50 & 0 & & 375 \\
\hline Total & 151 & 337 & 953 & 44 & 69 & 34 & 407 & 307 & 1 & 2 & 169 & 122 & 0 & 70 & 2666 \\
\hline
\end{tabular}

Table 2: Descriptive Statistics

\begin{tabular}{|l|c|c|c|c|c|c|}
\hline & Lambda & IPR & $\begin{array}{c}\text { Transfer } \\
\text { Efficiency }\end{array}$ & Herfindahl & Knowledge Pool & Firm size \\
\hline Mean & 0.093004 & 0.988099 & 0.019355 & 6.421857 & 1.297751 & 0.145980 \\
\hline Median & 0.001291 & 1.000000 & 0.011294 & 0.700208 & 0.279103 & 0.066902 \\
\hline Maximum & 1.000000 & 1.315108 & 0.484728 & 600.2644 & 38.00000 & 1.000000 \\
\hline Minimum & 0.000000 & 0.605023 & $2.82 \mathrm{E}-06$ & $2.59 \mathrm{E}-06$ & 0.000000 & 0.000000 \\
\hline Std. Dev. & 0.222236 & 0.128464 & 0.034699 & 32.70081 & 3.080382 & 0.215557 \\
\hline Observations & 972 & 972 & 972 & 972 & 972 & 972 \\
\hline
\end{tabular}


Table 3: Tobit estimates for lambda

\begin{tabular}{|c|c|}
\hline Variable & Coefficient \\
\hline IPR & $\begin{array}{r}0.4409 * * * \\
(0.0863)\end{array}$ \\
\hline IPR*Lead & $\begin{array}{r}0.1079 * * * \\
(0.0376) \\
\end{array}$ \\
\hline Transfer Efficiency & $\begin{array}{r}1.8543 * * * \\
(0.5064) \\
\end{array}$ \\
\hline Transfer Efficiency $*$ Lead & $\begin{array}{r}-1.6669^{*} \\
(0.8543)\end{array}$ \\
\hline Herfindahl & $\begin{array}{r}0.0018 * * * \\
(0.0005)\end{array}$ \\
\hline Herfindahl* Lead & $\begin{array}{r}-0.0046^{* *} \\
(0.0018)\end{array}$ \\
\hline Knowledge Pool & $\begin{array}{r}0.0126 * * * \\
(0.0042)\end{array}$ \\
\hline Knowledge Pool*Lead & $\begin{array}{r}-0.0084 \\
(0.0230)\end{array}$ \\
\hline Firm Size & $\begin{array}{r}0.8337 * * * \\
(0.0468)\end{array}$ \\
\hline Constant & $\begin{array}{r}-0.6563 * * * \\
(0.0889) \\
\end{array}$ \\
\hline Observations & 972 \\
\hline Log Likelihood & -344.28964 \\
\hline LR chi2 & 413.48 \\
\hline Prob $>$ chi2 & 0.0000 \\
\hline Pseudo R2 & 0.3752 \\
\hline
\end{tabular}

Notes: Estimated with two-limit $(0,1)$ Tobit; ${ }^{*}{ }^{* *}$, indicate significance at $0.1,0.05$, and 0.01 levels, respectively; standard errors in parentheses. 


\section{Appendix A. Existence of Equilibrium and Stability Conditions}

Using the reaction functions:

$R_{1}\left(\lambda_{1}\right)=\frac{b(1+\beta)\left[(g-1) \gamma G_{1}+s \alpha(1-\mu) X_{1}\right]-\delta \lambda_{1} X_{1}}{2 b s \alpha(1+\beta)(1-\mu) X_{1}}$ and

$R_{2}\left(\lambda_{1}\right)=\frac{\left.b(1+\beta)[(1-g)) G_{1}+\alpha(1-\mu) X_{1}\right]-2 b(1+\beta) \alpha(1-\mu) X_{1} \lambda_{1}}{s \delta X_{1}}$

Existence and stability conditions for the Nash equilibrium require that:

1. $\frac{b(1+\beta)\left[(g-1) \gamma G_{1}+s \alpha(1-\mu) X_{1}\right]-\delta \lambda_{1} X_{1}}{2 b s \alpha(1+\beta)(1-\mu) X_{1}}>\frac{b(1+\beta)\left[(1-g) \gamma G_{1}+\alpha(1-\mu) X_{1}\right]}{s \delta X_{1}}$, which gives:

$\delta>\frac{2 b \alpha(1+\beta)(1-\mu)\left[\gamma(1-g) G_{1}+\alpha(1-\mu) X_{1}\right]}{\gamma(g-1) G_{1}+s \alpha(1-\mu) X_{1}}$ iff $g>1-\frac{s \alpha(1-\mu) X}{\gamma G_{1}}$.

2. $\frac{\partial R_{1}\left(\lambda_{1}\right)}{\partial \lambda_{1}}<\frac{\partial R_{2}\left(\lambda_{1}\right)}{\partial \lambda_{1}}$ or $-\frac{\delta X_{1}}{2 b s \alpha(1+\beta)(1-\mu) X_{1}}<-\frac{2 b \alpha(1+\beta)(1-\mu) X_{1}}{s \delta X_{1}}$ which gives:

$\delta>2 b \alpha(1+\beta)(1-\mu)$. 


\section{Appendix B. Proofs of Propositions}

Proposition 1:

$$
\begin{aligned}
& \frac{\partial \lambda_{1}^{*}}{\partial \alpha}=\frac{b(1+\beta)(\mu-1)\left[-2 b(g-1)(1+\beta) \gamma(\delta-2 b \alpha(1+\beta)(\mu-1))^{2} G_{1}-\delta\left(s \delta^{2}+4 b \alpha(1+\beta) \delta(\mu-1)+4 b^{2} s \alpha^{2}(1+\beta)^{2}(\mu-1)^{2}\right) X_{1}\right]}{\left(\delta^{2}-4 b^{2} \alpha^{2}(1+\beta)^{2}(\mu-1)^{2}\right)^{2} X_{1}} \\
& \frac{\partial \lambda_{1}^{*}}{\partial \alpha}<0 \text { iff } s<s_{1}^{\alpha}, \text { where } s_{1}^{\alpha} \equiv \frac{2 b(1+\beta)\left[-(g-1) \gamma(\delta-2 b \alpha(1+\beta)(\mu-1))^{2} G_{1}-2 \alpha \delta^{2}(\mu-1) X_{1}\right]}{\delta\left[\delta^{2}+4 b^{2} \alpha^{2}(1+\beta)^{2}(\mu-1)^{2}\right] X_{1}} \\
& \frac{\partial \lambda_{2}^{*}}{\partial \alpha}=\frac{b(1+\beta)(\mu-1)\left[2 b(g-1)(1+\beta) \gamma(\delta-2 b \alpha(1+\beta)(\mu-1))^{2} G_{1}-\delta\left(\delta^{2}+4 s b \alpha(1+\beta) \delta(\mu-1)+4 b^{2} \alpha^{2}(1+\beta)^{2}(\mu-1)^{2}\right) X_{1}\right]}{s\left(\delta^{2}-4 b^{2} \alpha^{2}(1+\beta)^{2}(\mu-1)^{2}\right)^{2} X_{1}} \\
& \frac{\partial \lambda_{2}^{*}}{\partial \alpha}>0 \text { iff } s<s_{2}^{\alpha}, \text { where } s_{2}^{\alpha} \equiv \frac{\left[2 b(1+\beta)(g-1) \gamma(\delta-2 b \alpha(1+\beta)(\mu-1))^{2} G_{1}-\delta\left(\delta^{2}+4 b^{2} \alpha^{2}(1+\beta)^{2}(\mu-1)^{2}\right) X_{1}\right]}{4 b \alpha \delta^{2}(1+\beta)(\mu-1) X_{1}}
\end{aligned}
$$

\section{Proposition 2:}

$$
\begin{aligned}
& \frac{\partial \lambda_{1}^{*}}{\partial \beta}=\frac{b\left[(g-1) \gamma \delta(\delta-2 b \alpha(1+\beta)(\mu-1))^{2} G_{1}-\alpha \delta\left(s \delta^{2}+4 b \alpha(1+\beta) \delta(\mu-1)+4 b^{2} s \alpha^{2}(1+\beta)^{2}(\mu-1)^{2}\right)(\mu-1) X_{1}\right]}{\left(\delta^{2}-4 b^{2} \alpha^{2}(1+\beta)^{2}(\mu-1)^{2}\right)^{2} X_{1}} \\
& \frac{\partial \lambda_{1}^{*}}{\partial \beta}<0 \text { iff } s<s_{1}^{\beta}, \text { where } s_{1}^{\beta} \equiv \frac{(g-1) \gamma(\delta-2 b \alpha(1+\beta)(\mu-1))^{2} G_{1}-4 b^{2} \alpha^{2}(1+\beta) \delta(\mu-1)^{2} X_{1}}{\alpha\left[\delta^{2}+4 b^{2} \alpha^{2}(1+\beta)^{2}(\mu-1)^{2}\right](\mu-1) X_{1}}
\end{aligned}
$$$$
\frac{\partial \lambda_{2}^{*}}{\partial \beta}=\frac{b\left[-(g-1) \gamma \delta(\delta-2 b \alpha(1+\beta)(\mu-1))^{2} G_{1}-\alpha \delta\left(\delta^{2}+4 b s \alpha(1+\beta) \delta(\mu-1)+4 b^{2} \alpha^{2}(1+\beta)^{2}(\mu-1)^{2}\right)(\mu-1) X_{1}\right]}{\left(\delta^{2}-4 b^{2} \alpha^{2}(1+\beta)^{2}(\mu-1)^{2}\right)^{2} s X_{1}}
$$$$
\frac{\partial \lambda_{2}^{*}}{\partial \beta}>0 \text { iff } s<s_{2}^{\beta} \text {, where } s_{2}^{\beta} \equiv \frac{-(g-1) \chi(\delta-2 b o(1+\beta)(\mu-1))^{2} G_{1}+\alpha\left(\delta^{2}+4 b^{2} \alpha^{2}(1+\beta)^{2}(\mu-1)^{2}\right)(\mu-1) X_{1}}{4 b \alpha^{2}(1+\beta) \delta(\mu-1)^{2}(\mu-1)^{2} X_{1}}
$$ 


\section{Proposition 3:}

$$
\begin{aligned}
& \frac{\partial \lambda_{1}^{*}}{\partial \mu}=\frac{b \alpha(1+\beta)\left[-2 b(g-1)(1+\beta) \gamma(\delta-2 b \alpha(1+\beta)(\mu-1))^{2} G_{1}-\delta\left(s \delta^{2}+4 b \alpha(1+\beta) \delta(\mu-1)+4 b^{2} s \alpha^{2}(1+\beta)^{2}(\mu-1)^{2}\right) X_{1}\right]}{\left(\delta^{2}-4 b^{2} \alpha^{2}(1+\beta)^{2}(\mu-1)^{2}\right)^{2} X_{1}} \\
& \frac{\partial \lambda_{1}^{*}}{\partial \mu}>0 \text { iff } s<s_{1}^{\mu}, \text { where } s_{1}^{\mu} \equiv \frac{2 b(1+\beta)\left[-(g-1) \gamma(\delta-2 b \alpha(1+\beta)(\mu-1))^{2} G_{1}-2 \alpha \delta^{2}(\mu-1) X_{1}\right]}{\delta\left[\delta^{2}+4 b^{2} \alpha^{2}(1+\beta)^{2}(\mu-1)^{2}\right] X_{1}} ;
\end{aligned}
$$

Hence $s_{1}^{\mu}=s_{1}^{\alpha}$.

$$
\begin{aligned}
& \frac{\partial \lambda_{2}^{*}}{\partial \mu}=\frac{b \alpha(1+\beta)\left[2 b(g-1)(1+\beta) \gamma(\delta-2 b \alpha(1+\beta)(\mu-1))^{2} G_{1}-\delta\left(\delta^{2}+4 s b \alpha(1+\beta) \delta(\mu-1)+4 b^{2} \alpha^{2}(1+\beta)^{2}(\mu-1)^{2}\right) X_{1}\right]}{s\left(\delta^{2}-4 b^{2} \alpha^{2}(1+\beta)^{2}(\mu-1)^{2}\right)^{2} X_{1}} \\
& \frac{\partial \lambda_{2}^{*}}{\partial \mu}<0 \text { iff } s<s_{2}^{\mu}, \text { where } s_{2}^{\mu} \equiv \frac{\left[2 b(1+\beta)(g-1) \gamma(\delta-2 b \alpha(1+\beta)(\mu-1))^{2} G_{1}-\delta\left(\delta^{2}+4 b^{2} \alpha^{2}(1+\beta)^{2}(\mu-1)^{2}\right) X_{1}\right] ;}{4 b \alpha \delta^{2}(1+\beta)(\mu-1) X_{1}} ;
\end{aligned}
$$

Hence $s_{2}^{\mu}=s_{2}^{\alpha}$.

\section{Proposition 4:}

$$
\begin{aligned}
& \frac{\partial \lambda_{1}^{*}}{\partial g}=\frac{b(1+\beta) \gamma(-\delta+2 b \alpha(1+\beta)(\mu-1)) G_{1}}{\left(-\delta^{2}+4 b^{2} \alpha^{2}(1+\beta)^{2}(\mu-1)^{2}\right) X_{1}} ; \frac{\partial \lambda_{1}^{*}}{\partial g}>0 \\
& \frac{\partial \lambda_{2}^{*}}{\partial g}=-\frac{b(1+\beta) \gamma(-\delta+2 b \alpha(1+\beta)(\mu-1)) G_{1}}{s\left(-\delta^{2}+4 b^{2} \alpha^{2}(1+\beta)^{2}(\mu-1)^{2}\right) X_{1}} ; \frac{\partial \lambda_{2}^{*}}{\partial g}<0
\end{aligned}
$$




\section{Appendix C: ISIC Industries}

\begin{tabular}{|l|r|}
\hline & ISICNO \\
\hline Food, Beverages and Tobacco & 1 \\
\hline Textiles, Clothing, Leather and Footwear & 2 \\
\hline Wood \& Furniture & 3 \\
\hline Paper, Printing and Publishing & 4 \\
\hline Chemicals & 5 \\
\hline Drugs \& Medicines & 6 \\
\hline Petroleum and Coal Products and Refinery & 7 \\
\hline Rubber and Plastic & 8 \\
\hline Non Metallic Mineral Products & 9 \\
\hline Iron \& Steel & 10 \\
\hline Non-Ferrous Metals & 11 \\
\hline Metal Products & 12 \\
\hline Non-Electrical Machinery & 13 \\
\hline Office, Computing and Accounting Machinery & 14 \\
\hline Electrical Machinery & 15 \\
\hline Radio, TV and Communication Equipment & 16 \\
\hline Shipbuilding and Repairing & 17 \\
\hline Motor Vehicles & 18 \\
\hline Aerospace \& Aircraft & 19 \\
\hline Other Transport Equipment & 20 \\
\hline Professional Goods/Medical \& optical \& precision equipment & 21 \\
\hline Other Manufacturing & 22 \\
\hline
\end{tabular}

